\title{
Phytophthora boehmeriae Revealed as the Dominant Pathogen Responsible for Severe Foliar Blight of Capsicum annuum in South India
}

\author{
P. Chowdappa, S. Madhura, B. J. Nirmal Kumar, S. P. Mohan Kumar, and K. R. Hema, Indian Institute of Horticultural Research, \\ Hesaraghatta Lake Post, Bangalore-560 089, India
}

\begin{abstract}
Chowdappa, P., Madhura, S., Nirmal Kumar, B. J., Mohan Kumar, S. P., and Hema, K. R. 2014. Phytophthora boehmeriae revealed as the dominant pathogen responsible for severe foliar blight of Capsicum annuum in South India. Plant Dis. 98:90-98.

Prior to 2011, foliar blight was not reported as a serious threat to hot pepper cultivation in India. During the June-to-January cropping season of 2011 and 2012, severe foliar blight epidemics were observed in Karnataka and Tamil Nadu states of India. In all, 52 Phytophthora isolates, recovered from blight-affected leaf tissues of hot pepper from different localities in Karnataka and Tamil Nadu states between 2011 and 2012, were identified: 43 isolates as $P$. boehmeriae and 9 isolates as $P$. capsici, based on morphology, a similarity search of internal transcribed spacer sequences at GenBank, polymerase chain reaction (PCR) restriction fragment length polymorphism patterns, and species-

specific PCR using $\mathrm{PC} 1 / \mathrm{PC} 2$ and $\mathrm{PB} 1 / \mathrm{PB} 2$ primer pairs. The isolates were further assessed for metalaxyl sensitivity and aggressiveness on hot pepper. All isolates of $P$. boehmeriae were metalaxyl sensitive while $P$. capsici isolates were intermediate in sensitivity. $P$. boehmeriae isolates were highly aggressive and produced significantly $(P<0.01)$ larger lesion than those of $P$. capsici isolates. Thus, emergence of $P$. boehmeriae was responsible for severe leaf blight epidemics on hot pepper in South India, although it is not serious pathogen on any crop in any part of the world. These results have epidemiological and management implications for the production of hot pepper in India.
\end{abstract}

Chili (Capsicum annuum L.) is one of the most widely cultivated vegetable crops worldwide, consumed in various forms such as fresh, dry powder, paste, and sauce (2). It enhances food palatability and also is rich in vitamin C (2). Chili is grown on 3.7 million hectares worldwide, with an annual production of 33.4 million tons, and on 0.9 million hectares in India, with an annual production of 1.6 million tons (23). India is the world's single largest producer and exporter of chilies (22) and its cultivation is mainly concentrated in Andhra Pradesh, Karnataka, Maharashtra, Gujarat, Tamil Nadu, and Orissa (46). Phytophthora blight caused by Phytophthora capsici Leonian is a major threat to pepper production $(6,7)$ and is ranked as the second most devastating disease worldwide (53). P. capsici causes a root and crown rot, as well as an aerial blight of leaves, fruit, and stems, on bell pepper (40). Other species of Phytophthora such as $P$. cactorum, P. cryptogea, $P$. drechsleri, $P$. infestans, $P$. citrophthora, $P$. megasperma, $P$. nicotianae ( $P$. parasitica), and $P$. palmivora have been reported to infect chili fruit after artificial inoculation (21), but natural disease incidence caused by these pathogens is not known.

P. boehmeriae, first isolated from leaf spot of Boehmeria nivea in Taiwan in 1927, was named by Sawada (42) and has subsequently been found to cause brown rot of citrus fruit, root rot of Pinus spp., cotton boll blight, basal rot of Gerald ton wax plant (Chamaelauciun uncinatum Schauer.), and gummosis on black wattle (Acacia mearnsii) $(4,19,21,25,52)$. P. boehmeriae has been reported only in Argentina, Australia, Brazil, China, Greece, Japan, and Papua New Guinea $(4,19,21,25,52)$. However, there are no previous published reports of $P$. boehmeriae causing serious disease epidemics on any crop. In India, the occurrence of Phytophthora blight caused by $P$. capsici was first observed on bell pepper in 2006 (13), but no major outbreaks occurred until 2011. During the southwest monsoon period (June to September) of 2011, in which prevailing wet weather conditions are ideal for

Corresponding author: P. Chowdappa, E-mail: pallem22@gmail.com

Accepted for publication 29 July 2013.

http://dx.doi.org/10.1094/PDIS-06-13-0601-RE

(C) 2014 The American Phytopathological Society disease development, severe leaf blight epidemics occurred in the hot-pepper-growing areas of Karnataka and Tamil Nadu states of India. The objective of the current study was to understand the phenotypic and genotypic characteristics of the Phytophthora isolates responsible for severe leaf blight of hot pepper in India.

\section{Materials and Methods}

Sample collection and isolate isolation. Isolates were obtained from naturally infected foliage and fruit samples of hot and bell pepper in different districts of Karnataka, Coimbatore, and Ooty in Tamil Nadu (Fig. 1), where severe disease epidemics occurred, during the southwest monsoon period (June to September) of 2011and 2012. When all the chili fields in these localities were infected, leaves or fruit with single lesions were collected. Each sample consisted of three infected leaves or fruit from each of five plants within a disease focus. The locality of the sample collection and the isolates used in this study are shown in Table 1. To obtain isolates, a small piece ( 5 by $5 \mathrm{~mm}$ ) of foliage and fruit tissue taken from the margin of the lesion was washed in sterile distilled water, surface sterilized in $70 \%$ ethanol for $30 \mathrm{~s}$, rinsed twice in sterile distilled water, and placed on carrot agar medium (CA). After incubation at $25 \pm 1{ }^{\circ} \mathrm{C}$ for 5 days, the isolates were obtained by transferring a hyphal tip to fresh CA. Isolates were maintained on CA slants at $4^{\circ} \mathrm{C}$ by periodical ( 2 to 3 months) subculturing.

Morphological characterization. Colony morphology and growth rate were determined on 7-day-old cultures grown on CA at $25 \pm 1^{\circ} \mathrm{C}$. Sporangia were obtained by flooding 7-day-old CA culture with water. The length and breadth of sporangia of each isolate were measured under a Zeiss light microscope Axioscope A1 (approximately $\times 400$ ) using Axio vision software. The length and breadth of 50 sporangia/isolate were obtained to calculate an average. Other morphological characteristics, including the shape of sporangia and the presence of papillae, were studied (Table 2).

Mating type determination. The mating types of all $P$. capsici isolates were determined by pairing with known A1 (98-75) or A2 (98-01) reference $P$. capsici isolates that were obtained from the Indian Institute of Spices Research, Calicut. Mycelial plugs $(5 \mathrm{~mm}$ in diameter) on CA from the advancing margin of 5-day-old cultures were placed together, $2 \mathrm{~cm}$ apart, on clarified V8 juice agar, incubated at $24^{\circ} \mathrm{C}$ in darkness for 21 days (39), then examined microscopically for the presence of oospores where the two colo- 
nies overlapped. The diameters of 50 oospores/isolate were measured using Axio vision software at $\times 400$ magnification by taking a measurement of the length and width at the widest point.

Chlamydospore production. Chlamydospore production was assessed using the submerged culture method (26). A single 5-mmdiameter plug from the advancing margin of each isolate grown on CA was transferred to $25 \mathrm{ml}$ of carrot broth in a $150-\mathrm{ml}$ conical flask, incubated in the dark at $25 \pm 2{ }^{\circ} \mathrm{C}$ for $24 \mathrm{~h}$, shaken vigorously for $5 \mathrm{~min}$, and then incubated for 5 days in the dark at $25 \pm 2{ }^{\circ} \mathrm{C}$. The carrot broth was removed from the conical flask and was replaced with $50 \mathrm{ml}$ of sterile distilled water. Cultures were incubated in a BOD incubator at $18 \pm 2{ }^{\circ} \mathrm{C}$ for 21 days in darkness and checked for the presence of chlamydospores under $\times 400$ magnification according to the method of Granke et al. (26).

Growth at $35^{\circ} \mathbf{C}$. To examine growth of the isolates at $35^{\circ} \mathrm{C}$ (21), a 5-mm-diameter CA plug from the advancing margin of a 5day-old culture of each isolate was inoculated to the center of six 80-mm-diameter CA plates. The plates were sealed with parafilm and incubated in the dark in a BOD incubator at $35^{\circ} \mathrm{C}$. Three independent experiments were conducted for each isolate. Each experiment contained three replicates. Each replicate consisted of six petri plates.

Metalaxyl sensitivity. Sensitivity to metalaxyl was determined on V8 juice agar plates amended with metalaxyl at 0,5 , or 100 $\mu \mathrm{g} / \mathrm{ml}$ and $25^{\circ} \mathrm{C}$. Metalaxyl was added to V8 juice agar medium at $50^{\circ} \mathrm{C}$ just prior to dispensing it into petri dishes. Agar blocks $(5$ $\mathrm{mm}$ in diameter) with active mycelia were taken from the colony margin of each isolate and transferred to the center of three replicate plates of metalaxyl-amended V8 juice agar. The same isolates grown on V8 juice agar plates without metalaxyl served as controls. Radial colony growth of each isolate was measured after 7 days of incubation, and the mean of the three replicates was calculated. The mean percent growth of each isolate on metalaxylamended agar compared with growth on unamended agar control plates was calculated. Isolates were classified as sensitive, intermediate, and resistant based on the parameters of Silvar et al. (45). Isolates were considered resistant if the colony diameter was $<40 \%$ of the nonamended control at 5 and $100 \mu \mathrm{g} / \mathrm{ml}$, isolates with a colony diameter $>40 \%$ of the nonamended control at $5 \mu \mathrm{g} / \mathrm{ml}$ but $<40 \%$ of the nonamended control at $100 \mu \mathrm{g} / \mathrm{ml}$ were classified as intermediate, and isolates with a colony diameter $>40 \%$ of the nonamended control at both 5 and $100 \mu \mathrm{g} / \mathrm{ml}$ were classified as metalaxyl resistant.

Aggressiveness. To measure the aggressiveness of the isolates, lesion size was recorded on detached leaflets of chili according to the method described by Ristaino (39). Chili 'Arka lohit' plants were grown for 6 weeks under greenhouse conditions. The fully expanded third or fourth leaves from the crown were detached and

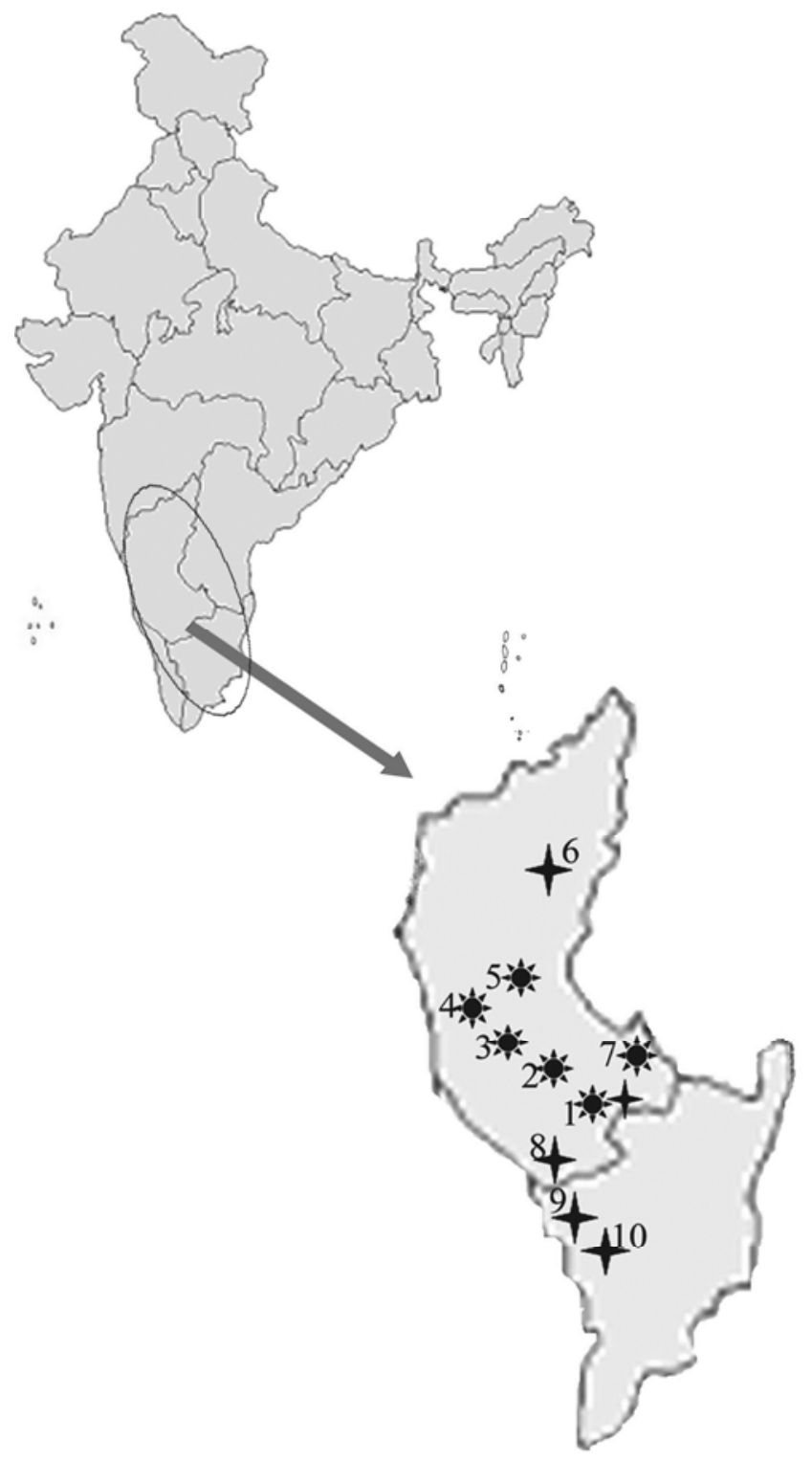

1.Bangalore Rural

Phytophthora capsici

2.Hassan

3.Chikmagalur

Phytophthora boehmeriae

4.Shivamogga

5.Davanegere

6.Bellary

7.Kolar

8.Mysore

9.0oty

10.Coimbatore

Fig. 1. Locations in South India where Phytophthora capsici and P. boehmeriae isolates were collected. 
placed on wet filter paper in $90-\mathrm{mm}$ petri dishes (two per dish). Each leaf was then inoculated with a $10 \mu \mathrm{l}$ droplet of sporangial suspension adjusted to a concentration of $2 \times 10^{4}$ sporangia $/ \mathrm{ml}$ on the ventral side (abaxial) of the main vein. Leaves were incubated at $25 \pm 1^{\circ} \mathrm{C}$ (16 h of light per day) and, after 7 days of incubation, lesions were measured. Three independent experiments were conducted for each isolate. Each experiment contained three replicates. Each replicate consisted of 12 leaves.

DNA extraction. To extract DNA, isolates were grown in carrot broth for 7 days at $25 \pm 1^{\circ} \mathrm{C}$. Mycelia were dried on filter paper

Table 1. Geographical origin of Phytophthora capsici and P. boehmeriae isolates ${ }^{\mathrm{Z}}$

\begin{tabular}{|c|c|c|c|c|c|c|c|}
\hline Isolate & Location & District & Crop & Source & $\begin{array}{l}\text { Metalaxyl } \\
\text { sensitivity }\end{array}$ & $\begin{array}{l}\text { GenBank } \\
\text { accession }\end{array}$ & NCBI identity \\
\hline OCPC1 & IIHR & Bangalore Rural & Chili & Stem & Intermediate & КC677803 & P. capsici \\
\hline OCPC2 & Rajankunte & Bangalore Rural & Chili & Stem & Intermediate & KC677804 & P. capsici \\
\hline OCPC3 & Rajankunte & Bangalore Rural & Bell pepper & Stem & Intermediate & KC677805 & P. capsici \\
\hline $\mathrm{OCPC} 4$ & Kurubarahalli & Bangalore Rural & Chili & Fruit & Sensitive & КC677806 & P. boehmeriae \\
\hline OCPC5 & Navillae & Shivamogga & Chili & Leaf & Sensitive & KC677807 & P. boehmeriae \\
\hline OCPC6 & Nurahonnae & Shivamogga & Chili & Fruit & Sensitive & КС677808 & P. boehmeriae \\
\hline OCPC7 & Bekanahalli & Shivamogga & Chili & Leaf & Sensitive & КС677809 & P. boehmeriae \\
\hline OCPC8 & Kumbaenahalli & Davanegere & Chili & Leaf & Sensitive & KC677810 & P. boehmeriae \\
\hline OCPC9 & Savalanya & Shivamogga & Chili & Leaf & Sensitive & KC677811 & P. boehmeriae \\
\hline OCPC10 & Abbigere & Bangalore Rural & Chili & Leaf & Sensitive & KC677812 & P. boehmeriae \\
\hline OCPC11 & Kodekoppa & Shivamogga & Chili & Leaf & Sensitive & KC677813 & P. boehmeriae \\
\hline OCPC12 & Nurahonnae & Shivamogga & Chili & Leaf & Sensitive & KC677814 & P. boehmeriae \\
\hline OCPC13 & Bellary & Bellary & Bell pepper & Stem & Intermediate & KC677815 & P. capsici \\
\hline OCPC14 & Bellary & Bellary & Bell pepper & Stem & Intermediate & KC677816 & P. capsici \\
\hline OCPC15 & Coimbatore & Coimbatore & Bell pepper & Stem & Intermediate & KC677817 & P. capsici \\
\hline OCPC16 & Mysore & Mysore & Bell pepper & Stem & Intermediate & KC677818 & P. capsici \\
\hline OCPC17 & Honavara & Bangalore Rural & Chili & Fruit & Sensitive & КС677819 & P. boehmeriae \\
\hline OCPC18 & Vadarahalli & Shivamogga & Chili & Leaf & Sensitive & KC677820 & P. boehmeriae \\
\hline OCPC19 & Mathkur & Bangalore Rural & Chili & Leaf & Sensitive & KC677821 & P. boehmeriae \\
\hline OCPC20 & Andralli & Kolar & Bell pepper & Leaf & Sensitive & KC677822 & P. boehmeriae \\
\hline OCPC21 & Thotadagere & Bangalore Rural & Chili & Leaf & Sensitive & KC677823 & P. boehmeriae \\
\hline $\mathrm{OCPC} 22$ & H.Cross & Kolar & Chili & Leaf & Sensitive & KC677824 & P. boehmeriae \\
\hline OCPC23 & Manchaenahalli & Bangalore Rural & Chili & Fruit & Sensitive & KC677825 & P. boehmeriae \\
\hline OCPC24 & Balepura & Kolar & Bell pepper & Leaf & Sensitive & KC677826 & P. boehmeriae \\
\hline OCPC25 & Hungenthi & Kolar & Chili & Fruit & Sensitive & KC677827 & P. boehmeriae \\
\hline OCPC26 & Dodathimanahalli & Bangalore Rural & Chili & Fruit & Sensitive & KC677828 & P. boehmeriae \\
\hline OCPC27 & Balenahalli & Kolar & Bell pepper & Leaf & Sensitive & КС677829 & P. boehmeriae \\
\hline OCPC28 & Hungenalli & Kolar & Chili & Leaf & Sensitive & KC677830 & P. boehmeriae \\
\hline OCPC29 & Thurnahalli & Kolar & Bell pepper & Leaf & Sensitive & KC677831 & P. boehmeriae \\
\hline OCPC30 & Thuruvanahalli & Bangalore Rural & Chili & Fruit & Sensitive & KC677832 & P. boehmeriae \\
\hline OCPC31 & Balepura & Kolar & Bell pepper & Fruit & Sensitive & KC677833 & P. boehmeriae \\
\hline OCPC 32 & Mangasandra & Kolar & Chili & Leaf & Sensitive & KC677834 & P. boehmeriae \\
\hline OCPC33 & Eragasandra & Kolar & Chili & Leaf & Sensitive & KC677835 & P. boehmeriae \\
\hline OCPC34 & Odagur & Kolar & Bell pepper & Leaf & Sensitive & KC677836 & P. boehmeriae \\
\hline OCPC35 & Hubanahalli & Chikmagalur & Chili & Leaf & Sensitive & KC677837 & P. boehmeriae \\
\hline OCРC36 & Guddahalli & Bangalore Rural & Chili & Leaf & Sensitive & КС677838 & P. boehmeriae \\
\hline OCPC37 & Golahalli & Bangalore Rural & Bell pepper & Leaf & Sensitive & КC677839 & P. boehmeriae \\
\hline OCPC38 & Shivakote & Bangalore Rural & Chili & Leaf & Intermediate & KC677840 & P. capsici \\
\hline OCPC39 & Rajankunte & Bangalore Rural & Chili & Fruit & Sensitive & $\ldots$ & P. boehmeriae \\
\hline OCPC40 & Devihalli & Hassan & Bell pepper & Leaf & Sensitive & KC677841 & P. boehmeriae \\
\hline OCPC41 & Jaldihalli & Chikmagalur & Chili & Leaf & Sensitive & KC677842 & P. boehmeriae \\
\hline OCPC42 & T-Agrahara & Kolar & Bell pepper & Leaf & Sensitive & KC677843 & P. boehmeriae \\
\hline OCPC43 & Ajampura & Chikmagalur & Chili & Leaf & Sensitive & KC677844 & P. boehmeriae \\
\hline OCPC44 & Sulibele & Kolar & Bell pepper & Leaf & Sensitive & KC677845 & P. boehmeriae \\
\hline OCPC45 & Yeliyuru & Kolar & Bell pepper & Leaf & Sensitive & KC677846 & P. boehmeriae \\
\hline OCPC46 & Siddapura & Chikmagalur & Chili & Leaf & Sensitive & КC677847 & P. boehmeriae \\
\hline OCPC47 & Valalu & Hassan & Bell pepper & Leaf & Sensitive & KC677848 & P. boehmeriae \\
\hline OCPC48 & Kumci & Chikmagalur & Bell pepper & Leaf & Sensitive & КС677849 & P. boehmeriae \\
\hline OCPC49 & Harnahalli & Chikmagalur & Chili & Leaf & Sensitive & KC677850 & P. boehmeriae \\
\hline OCPC50 & Malenahalli & Chikmagalur & Chili & Leaf & Sensitive & KC677851 & P. boehmeriae \\
\hline OCPC51 & Rajankunte & Bangalore Rural & Chili & Leaf & Sensitive & KC677852 & P. boehmeriae \\
\hline OCPC52 & Ooty & Ooty & Chili & Leaf & Intermediate & KC677853 & P. capsici \\
\hline
\end{tabular}

${ }^{\mathrm{z}}$ Data shown include isolate number, location, host, source, metalaxyl sensitivity, GenBank accession number, and National Center for Biotechnology Information (NCBI) identity.

Table 2. Morphological characteristics of Phytophthora boehmeriae and P. capsici isolates ${ }^{\mathrm{z}}$

\begin{tabular}{|c|c|c|c|c|c|c|c|c|}
\hline Species & $\begin{array}{c}\text { Growth rate } \\
\text { at } 24^{\circ} \mathrm{C} \\
(\mathrm{mm} / \mathrm{day})\end{array}$ & $\begin{array}{c}\text { Sporangial } \\
\text { morphology }\end{array}$ & $\begin{array}{c}\text { Length } \\
(\boldsymbol{\mu m})\end{array}$ & $\begin{array}{c}\text { Breadth } \\
(\mu \mathrm{m})\end{array}$ & $L / B$ ratio & $\begin{array}{c}\text { Stalk } \\
\text { length }\end{array}$ & $\begin{array}{c}\text { Mating } \\
\text { type }\end{array}$ & Oospore diameter \\
\hline $\begin{array}{l}\text { P. boehmeriae } \\
\text { (43 isolates) }\end{array}$ & $\begin{array}{l}7.61 \pm 0.055 \\
(6.79-8.02)\end{array}$ & Globose & $\begin{array}{c}35.33 \pm 4.77 \\
(32.76-38.80)\end{array}$ & $\begin{array}{c}20.49 \pm 3.42 \\
(18.21-28.57)\end{array}$ & $\begin{array}{c}1.74 \pm 0.20 \\
(1.22-1.96)\end{array}$ & $\begin{array}{l}4.13 \pm 0.58 \\
(3.02-4.8)\end{array}$ & $\mathrm{H}$ & $\begin{array}{l}22.48 \pm 3.92 \\
(21.9-25.1)\end{array}$ \\
\hline $\begin{array}{l}\text { P. capsici } \\
\text { (9 isolates) }\end{array}$ & $\begin{array}{l}7.62 \pm 0.061 \\
(7.1-8.2)\end{array}$ & Lemoniform & $\begin{array}{c}43.57 \pm 6.67 \\
(24.26-43.31)\end{array}$ & $\begin{array}{c}28.04 \pm 3.24 \\
(17.63-23.52)\end{array}$ & $\begin{array}{c}1.55 \pm 0.08 \\
(1.29-1.95)\end{array}$ & $\begin{array}{c}51.33 \pm 15.61 \\
(42.55-75.58)\end{array}$ & A1 & $\begin{array}{c}32.25 \pm 3.28 \\
(31.64-34.10)\end{array}$ \\
\hline
\end{tabular}

\footnotetext{
${ }^{\mathrm{z}}$ Mean of isolates, range in parentheses. $\mathrm{L} / \mathrm{B}=$ length/breadth. $\mathrm{H}=$ homothallic.
} 
and ground in a mortar and pestle using liquid nitrogen. DNA was isolated from the powdered mycelia according to the procedure described by Raeder and Broda (38) and slightly modified by Chowdappa et al. (12) and stored at $-20^{\circ} \mathrm{C}$ until use.

Amplification of internal transcribed spacer region of ribosomal DNA, cloning, and sequencing. The ribosomal DNA (rDNA) containing the partial $18 \mathrm{~S}$ and $28 \mathrm{~S}$ ribosomal region along with the internal transcribed spacer (ITS)1, ITS2, and 5.8S rRNA genes was amplified from all the isolates with ITS1 (5'-TCC GTAGGTGAACCTGCGG-3') and ITS4 (5'-TCCTCCGCTTAT TGATATGC-3') primers (51). The polymerase chain reaction (PCR) reaction mixture consisted of $5 \mu$ of $10 \times$ PCR buffer, 40.75 $\mu \mathrm{l}$ of sterile distilled water, $1 \mu \mathrm{l}$ of $2.0 \mathrm{mM}$ dNTPs, $1 \mu \mathrm{l}$ each of 50 $\mathrm{pM}$ primers ITS1 and ITS4, $0.25 \mu \mathrm{l}$ of Taq polymerase $(5 \mathrm{U} / \mu \mathrm{l})$ (Merck Bio Sciences), and $1 \mu \mathrm{l}$ of genomic DNA for a total volume of $50 \mu \mathrm{l}$. Amplification conditions were as follows: $95^{\circ} \mathrm{C}$ for $3 \mathrm{~min}$; followed by 35 cycles $95^{\circ} \mathrm{C}$ for $30 \mathrm{~s}, 55^{\circ} \mathrm{C}$ for $45 \mathrm{~s}$, and $72^{\circ} \mathrm{C}$ for 1 $\mathrm{min}$; followed by a final extension of $72^{\circ} \mathrm{C}$ for $10 \mathrm{~min}$. PCR products were analyzed by electrophoresis in $2 \%$ (wt/vol) agarose gel in $1 \times$ Tris borate-EDTA buffer, stained with ethidium bromide ( 5 $\mu \mathrm{g} / \mathrm{ml}$ ), and visualized by Alpha imager EP (Alpha Innotech Corporation). The resulting PCR product was ligated into pTZ57R/T vector and transformed into Escherichia coli $\mathrm{DH} 5 \alpha$. The plasmid was purified from E. coli and the cloned DNA fragment was sequenced to identify the isolates with previously reported rDNA sequences of Phytophthora spp.

PCR restriction fragment length polymorphism analysis. The ITS PCR product of all the isolates, generated by primer pair ITS6
(5'-GAAGGTGAAGTCGTAACAAGG-3') and ITS4 as described earlier (18), were digested with different restriction enzymes (AluI, $M s p I$, and $T a q \mathrm{I}$ ), as per the manufacturer's recommendations. Further, a genus-specific amplicon obtained using forward primer A2 (5'-ACTTTCCACGTGAACCGTTTCAA-3') in combination with reverse primer I2 (5'-GATATCAGGTCCAATTGAGATGC-3') (20), was also subjected to three different restriction enzymes (MspI, RsaI, and TaqI). The digested products were electrophoresed on a $3 \%$ NuSieve agarose gel in $1 \times$ Tris borate-EDTA buffer, stained with ethidium bromide $(5 \mu \mathrm{g} / \mathrm{ml})$, and visualized by Alpha imager EP (Alpha Innotech Corporation).

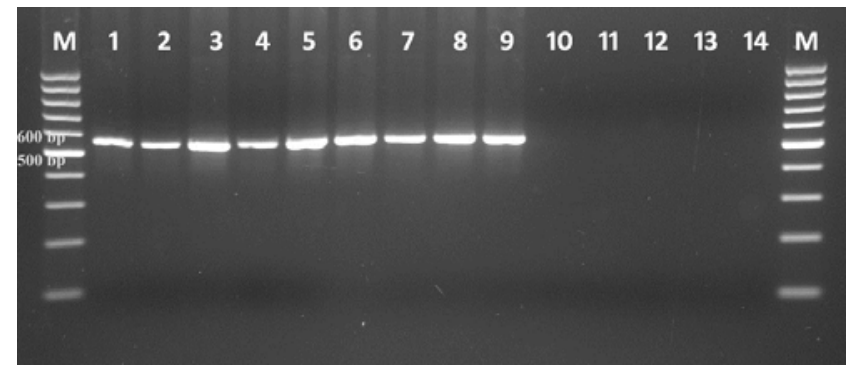

Fig. 3. Polymerase chain reaction amplification products of Phytophthora capsici using specific PC-1 and PC-2 primers. Lane M, 100-bp ladder; lane 1, OCPC1; lane 2, OCPC2; lane 3, OCPC3; lane 4, OCPC13; lane 5, OCPC14; lane 6, OCPC15; lane 7, OCPC 16; lane 8, OCPC 38; lane 9, OCPC 52; lane 10, OCPC 4; lane 11, OCPC 5; lane 12, OCPC 6; lane 13, OCPC 7; lane 14, OCPC 8.

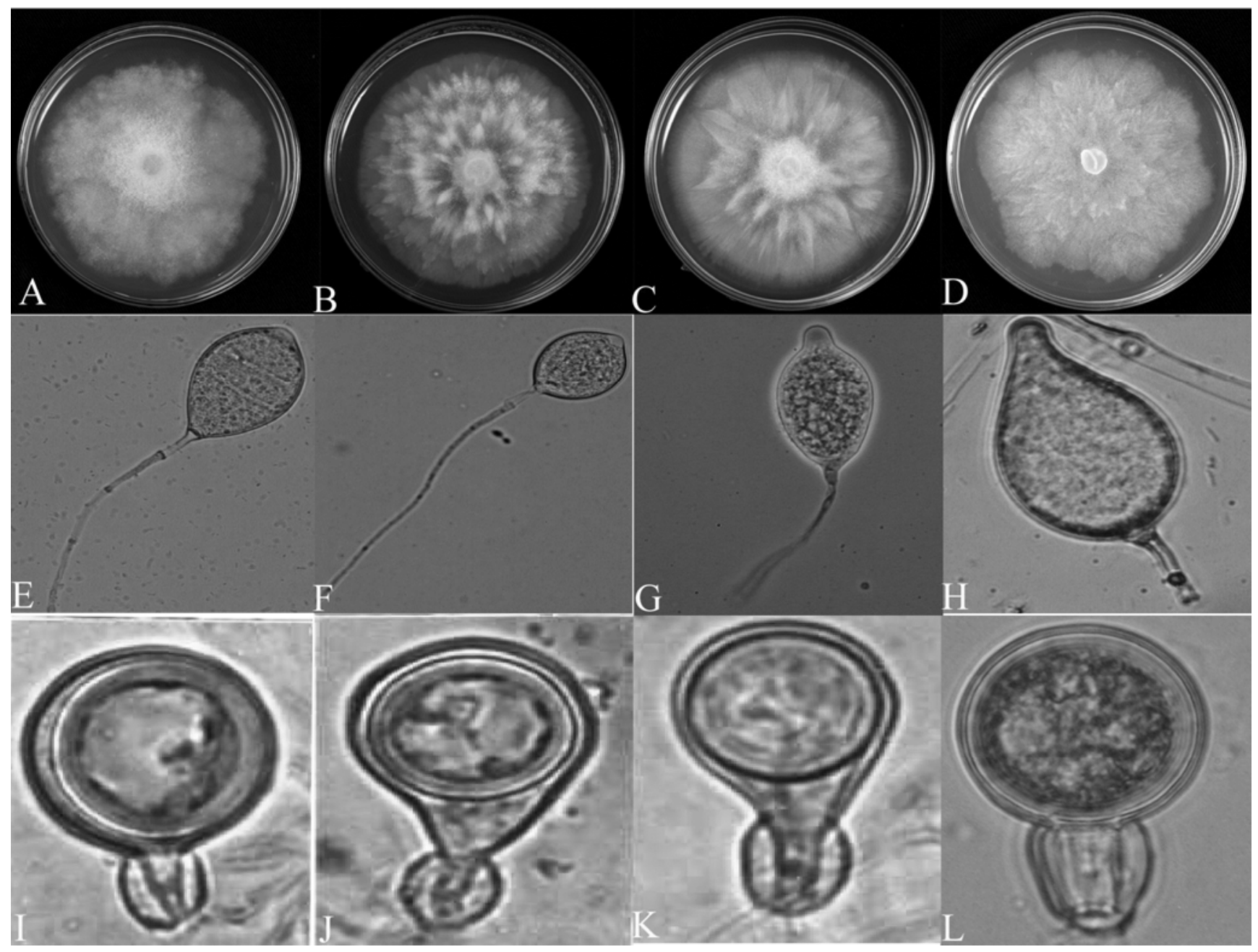

Fig. 2. Colony, sporangial, and oogonial morphology of Phytophthora boehmeriae and $P$. capsici isolates. A-C, Colony morphology of $P$. capsici; $\mathbf{D}$, colony morphology of $P$. boehmeriae; E-G, sporangial morphology of $P$. capsici; $\mathbf{H}$, sporangial morphology of $P$. boehmeriae; I-K, oogonial morphology of $P$. capsici; $\mathbf{L}$, oogonial morphology of $P$. boehmeriae. 
Amplification with specific primer. All isolates were amplified using the $P$. capsici-specific primers PC-1 (5'-GTCTTG TACCCTATCATGGCG-3') and PC-2 (5'-CGCCACAGCAGG AAAAGCATT-3') (54) and $P$. boehmeriae-specific primers PB1 (5'-CGGCTTTCGGGCTGCTGC-3') and PB2 (5'-ATACCCGAA GGCAAAGCGC-3') (43). PCR reaction mixture consisted of $5 \mu \mathrm{l}$ of $10 \times$ PCR buffer, $40.75 \mu \mathrm{l}$ of sterile distilled water, $1 \mu \mathrm{l}$ of 2.0 $\mathrm{mM}$ dNTPs, $1 \mu \mathrm{l}$ each of $50 \mathrm{pM}$ primers PC1/PC-2 or PB1/PB2, $0.25 \mu \mathrm{l}$ of Taq polymerase $(5 \mathrm{U} / \mu \mathrm{l})$ (Merck Bio Sciences), and $1 \mu \mathrm{l}$ of genomic DNA for a total volume of $50 \mu$ l. Amplification conditions for $\mathrm{PC} 1 / \mathrm{PC} 2$ were $95^{\circ} \mathrm{C}$ for $3 \mathrm{~min}$; followed by 35 cycles of $95^{\circ} \mathrm{C}$ for $30 \mathrm{~s}, 55^{\circ} \mathrm{C}$ for $45 \mathrm{~s}$, and $72^{\circ} \mathrm{C}$ for $1 \mathrm{~min}$; followed by a final extension of $72^{\circ} \mathrm{C}$ for $10 \mathrm{~min}$. Thermal cycling parameters for $\mathrm{PB} 1 / \mathrm{PB} 2$ were initial denaturation at $94^{\circ} \mathrm{C}$ for $5 \mathrm{~min}$; followed by 35 cycles of denaturation at $94^{\circ} \mathrm{C}$ for $30 \mathrm{~s}$, annealing at $62^{\circ} \mathrm{C}$ for $40 \mathrm{~s}$ and, extension at $72^{\circ} \mathrm{C}$ for $1 \mathrm{~min}$; followed by a final extension of $72^{\circ} \mathrm{C}$ for $8 \mathrm{~min}$.

Phylogenetic analysis. Phylogenetic relationships among all the sequences were inferred by maximum parsimony (MP) analysis using MEGA5.0 software (47). The sequences of $P$. boehmeriae, $P$. kernoviae, $P$. gallica, $P$. morindae (clade 10), $P$. capsici, and $P$. tropicalis (clade 4) were also included in the phylogenetic analysis. The analysis was bootstrapped with 1,000 replicates to determine the support for various clades of the trees. In total, 10 replicates were used for the random addition of samples to construct the tree. The MP tree was obtained using the close-neighbor-interchange algorithm (34) with search level 1 , in which the initial trees were obtained with the random addition of sequences (10 replicates). The tree was drawn to scale, with branch lengths calculated using the average pathway method and, in units, of the number of changes over the whole sequence.

\section{Results}

In all, 52 isolates of Phytophthora spp. were obtained from leaf blight infected chili samples. Of these, 43 isolates $(83 \%)$ fit the description of $P$. boehmeriae (25) and 9 isolates (17\%) fit the description of $P$. capsici (26) (Table 2).

Morphological identification. Cultures of $P$. boehmeriae exhibited no distinct colony pattern (Fig. 2), with a growth rate of 6.79 to $8.02 \mathrm{~mm} /$ day (Table 2). In contrast, isolates of $P$. capsici had either cottony or petaloid growth patterns (Fig. 2), with a growth rate of $7 \mathrm{~mm} /$ day Sporangia of $P$. boehmeriae were borne on simple sporangiophores. They were caducous and papillate. Most of the sporangia were globose, ovoid to ellipsoid, or nearly spherical or obturpinate to obpyriform (Fig. 2). The length of the sporangia was 32.76 to $38.80 \mu \mathrm{m}$ and breadth varied from 18.21 to 28.57 $\mu \mathrm{m}$, with a length-to-breadth (L:B) ratio of 1.22 to 1.96 . The pedicel length of the isolates was less than $<5 \mu \mathrm{m}$. Sporangia of $P$. capsici isolates were also caducous and papillate. Sporangia were mostly lemoniform or ellipsoid with tapered base and some were obpyriform (Fig. 2). They carried a long stalk, varying from 42.55 to $75.58 \mu \mathrm{m}$. The sizes of the sporangia of $P$. capsic $i$ were 24.26 to 43.31 by 17.63 to $23.5258 \mu \mathrm{m}$, with an L:B ratio of 1.29 to 1.95 .

All 43 isolates of $P$. boehmeriae were homothallic and readily produced oospores on carrot agar plates. All nine isolates of $P$. capsici were heterothallic and belonged to the A1 mating type. All of the oospores examined in both species had amphigynous antheridia. The mean diameter of the oospores of $P$. capsici isolates was 31.64 to $34.10 \mu \mathrm{m}$, greater than those of P. boehmeriae (21.9 to $25.1 \mu \mathrm{m})$.Of the nine isolates of $P$. capsici, two isolates produced chlamydospores. Among the 43 isolates of $P$. boehmeriae, 27 isolates produced chlamydospores. All $P$. capsici and $P$. boehmeriae failed to grow at $35^{\circ} \mathrm{C}$. All P. boehmeriae isolates were sensitive to metalaxyl whereas $P$. capsici isolates were intermediate in sensitivity.

Molecular identification. Amplification of DNA from nine $P$. capsici isolates with primers $\mathrm{PC} 1$ and $\mathrm{PC} 2$ produced $\mathrm{PCR}$ product of $560 \mathrm{bp}$ (Fig. 3), as expected for $P$. capsici, and no amplification was detected from the DNA of 43 isolates of P. boehmeriae. Similarly, PCR amplification of DNA of $P$. boehmeriae using primers PB1 and PB2 yielded a single PCR product of $750 \mathrm{bp}$ but no amplification was achieved from $P$. capsici isolates (data not shown). The digestion of an ITS-PCR amplicon with AluI, MspI, and TaqI resulted in characteristic fingerprints specific to $P$. capsici and $P$. boehmeriae (Table 3; Fig. 4). The restriction digestion profiles generated by MspI, RsaI, and TaqI on the resulting amplicon obtained using the genus-specific primers A2 and $\mathrm{I} 2$ also separated $P$. capsici and P. boehmeriae (Table 4; Fig. 5).

Phylogenetic analysis. The MP analysis of ITS gene sequences resulted in detection of two main clades (Fig. 6). Clade I consisted of $43 \mathrm{P}$. boehmeriae isolates characterized by globose sporangia with short pedicels that were homothallic. Clade 2 comprised nine isolates of $P$. capsici and had lemoniform sporangia with long pedicels that were heterothallic. Comparisons with sequences of $P$. boehmeriae, $P$. capsici, and $P$. tropicalis isolates downloaded from GenBank also revealed a clear separation. P. boehmeriae isolates formed two subgroups in clade 1. All isolates of $P$. boehmeriae examined in this study formed as subgroup I, along with isolates CBS29129 (National Center for Biotechnology Information accession number HQ 643149) from Japan and P6950 (HQ 2261504) from Taiwan downloaded from GenBank; and isolates from Argentina, South Africa, and Papua New Guinea formed subgroup II. Our $P$. capsici isolates clustered with ITS sequences of $P$. capsici isolates downloaded from GenBank under subgroup I of clade 2 while the $P$. tropicalis isolate from GenBank formed as subgroup II under clade 2.

Aggressiveness. The wound drop inoculation on detached leaves of Capsicum annuum Arka lohit with the $P$. boehmeriae and $P$. capsici isolates produced typical symptoms with white mycelia growth and sporangia after 6 days of inoculation. They differed significantly in lesion sizes (Table 5). P. boehmeriae isolates were highly aggressive and produced significantly $(P<0.01)$ larger lesion than those of $P$. capsici isolates.

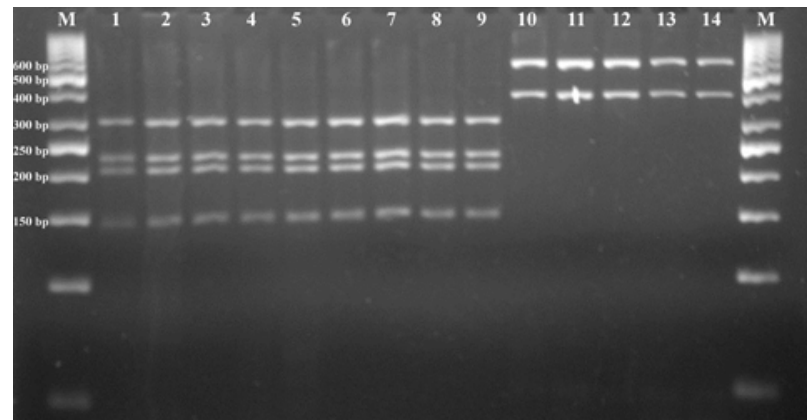

Fig. 4. Restriction fragment length polymorphism patterns of internal transcribed spacer (ITS) region after polymerase chain reaction using ITS6 and ITS4 primer pair and restriction digestion with restriction enzymes Mspl. Lane M, 50-bp ladder; lane 1 OCPC 1; lane 2, OCPC 2; lane 3, OCPC 3; lane 4, OCPC 13; lane 5, OCPC 14; lane 6, OCPC 15; lane 7, OCPC 16; lane 8, OCPC 38; lane 9, OCPC 52; lane 10, OCPC 4; lane 11, OCPC 5; lane 12, OCPC 6; lane 13, OCPC 7; lane 14, OCPC 8.

Table 3. Size (bp) of restriction fragments for Phytophthora spp. amplified with primers internal transcribed spacer (ITS)6 and ITS4 and digested with the restriction enzymes ${ }^{z}$

\begin{tabular}{lccc}
\hline Phytophthora sp. & PCR amplicon (bp) & AluI & MspI \\
\hline P. boehmeriae & 900 & $565,210,170$ & 570,387 \\
P. capsici & 860 & $535,172,155$ & $292,221,204,145$ \\
\hline
\end{tabular}

z Amplified products were digested with the indicated restriction enzyme and separated in a $3 \%$ agarose gel. PCR $=$ polymerase chain reaction. 


\section{Discussion}

Proper identification of Phytophthora spp. responsible for foliar blights in chili is crucial for developing effective disease management strategies and also for the selection of the appropriate pathogen isolates to use in resistance screening programs. A combined application of morphological characters, molecular diagnostic tools, and pathogenicity led to identification of $P$. capsici and $P$. boehmeriae responsible for severe outbreaks of leaf blight in chili in South India. This is the first report of the involvement of $P$. boehmeriae in the causation of foliar blight of chili in India. $P$. boehmeriae was first reported from Taiwan on B. niver in 1927 (42) and has been known to infect only B. niver, Broussonetia papyriera, Gossypium spp., citrus, Pinus spp., and A. mearnsi in Australia, Argentina, Brazil, China, Greece, Japan, Papua New Guinea, Taiwan, and South Africa $(19,21,25,36,43)$. P. capsici is distributed worldwide (21) and is a serious pathogen of vegetable crops in the families Cucurbitaceae, Solanaceae, and Fabaceae (27) and on nonvegetable hosts such as cacao (Theobroma cacao L.), rubber (Hevea brasiliensis Mull. Arg.), macadamia (Macadamia integrifolia Maiden \& Betche), papaya (Carica papaya L.), and black pepper (Piper nigrum L.) (21).

Previously, sporangium morphology (including pedicel length and presence or absence of chlamydospores), growth at $35^{\circ} \mathrm{C}$, oospore diameters $(5,26)$, species-specific PCR (44), PCR amplification and sequencing $(8,37)$, and restriction enzyme digestion patterns $(8,33)$ have been used to identify, characterize, and separate $P$. capsici from closely related species. In the present study, P. capsici sporangia were caducous and papillate, with long pedicles of 43 to $75 \mu \mathrm{m}$ in length, in agreement with other studies that reported pedicle lengths of sporangia of 24 to $177 \mu \mathrm{m}(5,26,28,33,39)$. In contrast, sporangia for isolates $P$. boehmeriae were also caducous and papillate, with short pedicles of $<5 \mu \mathrm{m}$, similar to the descriptions reported in previous studies $(21,25,52)$. In this study, the mean sporangial length and breadth for each $P$. capsici isolate was 24 to $43 \mu \mathrm{m}$ long and 17 to $23 \mu \mathrm{m}$ wide, with an L:B ratio (1.29 to1.95) which falls within the range of 38 to $60 \mu \mathrm{m}$ long and 23 to $35 \mu \mathrm{m}$ wide and an $\mathrm{L}: \mathrm{B}$ ratio (1.34 to 2.07 ) that were reported in a previous study by Granke et al. (26) using worldwide collection of P. capsici isolates. Prior to 2011 , many studies have also shown that similar mean sporangial length varied from 33 to $66 \mu \mathrm{m}$ long and 17 to $43 \mu \mathrm{m}$ wide $(5,28,33,39)$. Ristaino (39) reported that sporangia of $P$. capsici isolates from pepper (39 to $60 \mu \mathrm{m}$ long) were shorter than isolates from cucurbit hosts (56 to $63 \mu \mathrm{m}$ long). $P$. boehmeriae isolates had sporangia that were 32 to $38 \mu \mathrm{m}$ long and 18 to $28 \mu \mathrm{m}$ wide, with an L:B ratio of 1.22 to 1.96 in our study. These sporangial measurements falls within the range reported for $P$. boehmeriae in earlier studies $(25,36,52)$.

In the present study, when cultures were incubated in liquid media, two of nine (22\%) P. capsici isolates and 27 of $43(51 \%) P$. boehmeriae isolates produced chlamydospores. In their study, Granke et al. (26) reported that $P$. capsici isolates from hosts in the families Cucurbitaceae, Fabaceae, and Solanaceae produced chlamydospores, and isolates retrieved from nonvegetable hosts produced no chlamydospores. In contrast, $P$. capsici isolates from solanaceous or cucurbitaceous hosts did not produce chlamydospores (39) but chlamydospores were produced by isolates from nonvegetable hosts $(3,50)$. Mchau and Coffey $(33)$ reported that 16 of $29(55 \%)$ CAP2 (P. tropicalis) isolates produced chlamydospores, but none of the CAP1 isolates that likely represent $P$. capsici sensu stricto isolates produced chlamydospores. Aragaki and Uchida (5) showed that no P. capsici isolates and most (46 of 53,
$87 \%)$ P. tropicalis isolates produced chlamydospores. Thus, chlamydospore production is not reliable character for distinction of $P$. capsici from $P$. tropicalis. Previous studies have reported chlamydospore production by some isolates of $P$. boehmeriae (25,36,52). P. capsici isolates were heterothallic and isolates belong to A1 mating type whereas $P$. boehmeriae isolates were homothallic, in agreement with previous studies $(25,26)$. Although no information is available on mating types of $P$. capsici isolates from pepper, the presence of both mating types in $P$. capsici isolates from cocoa has been recorded in India (14). Oospore diameters for $P$. capsici isolates were 31.64 to $34.10 \mu \mathrm{m}$ in our study, which is in agreement with earlier studies $(26,28,33,39)$. In contrast, oospore diameters of $P$. boehmeriae are smaller $(21.9$ to $25.1 \mu \mathrm{m})$ than those of $P$. capsici and sizes fall within the ranges reported for $P$. boehmeriae $(25,36,52)$. Earlier studies have demonstrated that growth at $35^{\circ} \mathrm{C}$ is a robust characteristic to separate $P$. capsici from $P$. tropicalis and other Phytophthora spp. $(5,8,33)$. In this study, $P$. capsici and $P$. boehmeriae isolates failed to grow at $35^{\circ} \mathrm{C}$. The maximum growth temperature for $P$. boehmeriae isolates was found to be $32.5^{\circ} \mathrm{C}$ (25). A previous study by Bowers et al. (8) showed that only temperate isolates of $P$. capsici grew at $35^{\circ} \mathrm{C}$ and tropical isolates did not.

In addition to morphological approaches, restriction fragment length polymorphism analysis of PCR-amplified ITS regions $(11,17,18,41,49)$ and amplicons obtained using the genus-specific primers A2 and I2 (20) have been used for discrimination of Phytophthora spp. In this study, restriction profiles of the ITS region of the rDNA gene cluster and amplicons generated by the genusspecific primers separated the $P$. capsici isolates from $P$. boehmeriae isolates. The identities of $P$. capsici and $P$. boehmeriae isolates were further confirmed by species-specific PCR $(43,54)$ and ITS sequence matches against those in GenBank. The ITS-based phylogenetic inference has been found to be highly robust in differentiating Phytophthora spp. (16). Our ITS sequence data clearly distinguished $P$. boehmeriae and $P$. capsici isolates. $P$. boehmeriae has been assigned to clade 10 within genus Phytophthora (31) along with other three homothallic species: $P$. gallica on oak and reed in Germany and France (29), P. kernoviae on beech in the United Kingdom (9), and P. morindae on noni in Hawaii (35). Comparison of ITS sequence data of $P$. boehmeriae isolates used in this study against sequences deposited in the GenBank showed that ITS se-

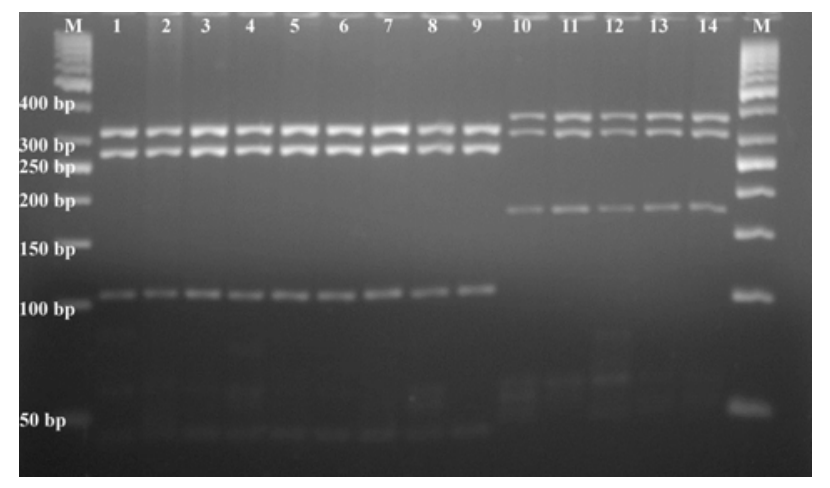

Fig. 5. Restriction fragment length polymorphism patterns of the amplicon after polymerase chain reaction using Phytophthora genus-specific primer pair A2-12 and restriction digestion with Rsal. Lane M, 50-bp ladder; lane 1, OCPC 1; lane 2, OCPC 2; lane 3, OCPC 3; lane 4, OCPC 13; lane 5, OCPC 14; lane 6, OCPC 15; lane 7, OCPC 16; lane 8, OCPC 38; lane 9, OCPC 52; lane 10, OCPC 4; lane 11, OCPC 5; lane 12, OCPC 6; lane 13, OCPC 7; lane 14, OCPC 8.

Table 4. Size (bp) of restriction fragments for Phytophthora spp. amplified with primers A2 and I2 and digested with the restriction enzymes ${ }^{\mathrm{Z}}$

\begin{tabular}{lcccc}
\hline Phytophthora sp. & PCR amplicon size $(\mathbf{b p})$ & $\boldsymbol{M s p \mathbf { I }}$ & $\boldsymbol{R} \boldsymbol{s} \mathbf{I}$ & Taq $\mathbf{I}$ \\
\hline P. boehmeriae & 828 & 515,313 & $351,303,174$ & $256,227,197,89,59$ \\
P. capsici & 752 & $281,250,221$ & $318,274,105$ & $194,194,149,90,60$ \\
\hline
\end{tabular}

${ }^{\mathrm{z}} \mathrm{PCR}=$ polymerase chain reaction. 
quences HQ 643149, FJ801955, HQ 261504, and GU 259127 generated from voucher CBS29129, clone WPC 6950A251, voucher P6950, and WPC 1387A15 of P. boehmeriae, respectively, clustered in the same subgroup I of group I in the parsimonious tree.
However, ITS sequences (deposited in the GenBank) GQ166763, FJ801479, and GU 963637 derived from isolates ph 698P0701 of $P$. morindae, ICMP14761 of P. kernoviae, and WPC 16827D2028 of $P$. gallica, respectively, clustered in subgroup II of group I. Simi-

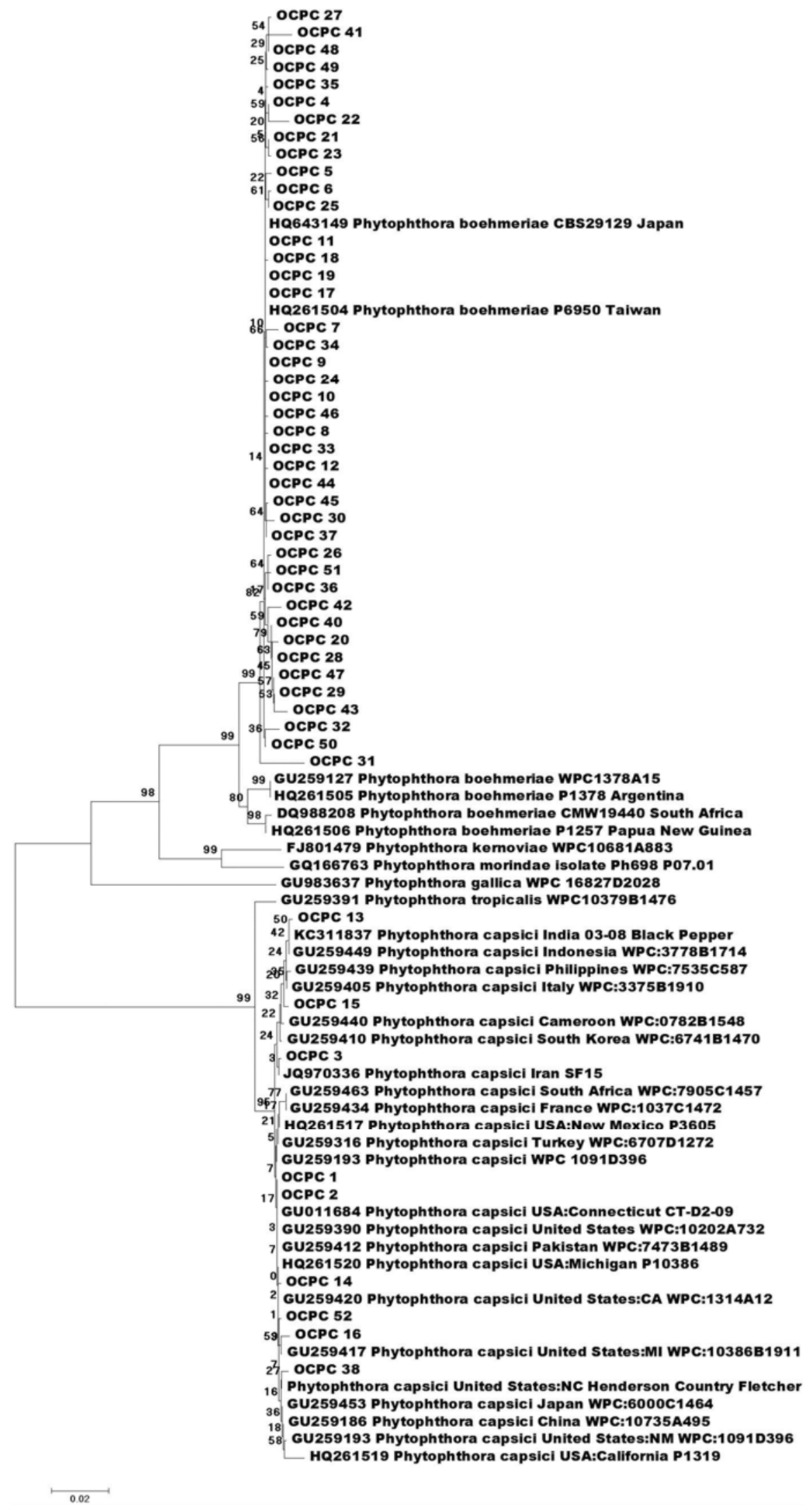

Fig. 6. Phylogenetic tree generated using maximum parsimony analysis of internal transcribed spacer gene sequences. Values above branching nodes represent percentage bootstrap support calculated from 1,000 replicates. Branch lengths are proportional to the numbers of nucleotide substitutions and are measured by scale bars (bar $=10 \%$ sequence divergence). 
larly, nine $P$. capsici isolates were clustered in group II along with ITS sequence GU 259193 generated from isolate WPC 1091D396 of $P$. capsici and sequence GU 259391 derived from $P$. tropicalis isolate WPC 10379B1476 formed as separate subgroup under group II.

Variations in sensitivity to metalaxyl have been reported within and between Phytophthora spp. $(15,30,48)$. In this study, isolates of $P$. boehmeriae collected in different locations in India from pep-

Table 5. Aggressiveness of Phytophthora capsici and P. boehmeriae isolates on 'Arka Lohit' chili

\begin{tabular}{|c|c|}
\hline Isolates & Lesion size $\left(\mathrm{cm}^{2}\right)^{y}$ \\
\hline \multicolumn{2}{|l|}{ P. capsici } \\
\hline OCPC 1 & $2.21 \pm 0.23 \mathrm{~m}$ \\
\hline OCPC 2 & $2.33 \pm 0.23 \mathrm{~m}$ \\
\hline ОСРC 3 & $2.39 \pm 0.12 \mathrm{~m}$ \\
\hline ОСРС 13 & $2.32 \pm 0.14 \mathrm{~m}$ \\
\hline ОСРС 14 & $2.37 \pm 0.11 \mathrm{~m}$ \\
\hline OCPC 15 & $2.50 \pm 0.19 \mathrm{~m}$ \\
\hline OCPC 16 & $2.65 \pm 0.20 \mathrm{~m}$ \\
\hline ОСРС 38 & $2.32 \pm 0.12 \mathrm{~m}$ \\
\hline ОСРC 52 & $2.24 \pm 0.15 \mathrm{~m}$ \\
\hline \multicolumn{2}{|c|}{ P. boehmeriae } \\
\hline ОСРC 4 & $3.44 \pm 0.22 \mathrm{j}$ \\
\hline OCPC 5 & $3.90 \pm 0.18 \mathrm{a}$ \\
\hline OCPC 6 & $3.63 \pm 0.16 \mathrm{~g}$ \\
\hline OCРC 7 & $3.85 \pm 0.23 \mathrm{~b}$ \\
\hline OCРC 8 & $3.45 \pm 0.20 \mathrm{j}$ \\
\hline ОСРС 9 & $4.02 \pm 0.24 \mathrm{a}$ \\
\hline OCPC 10 & $3.85 \pm 0.10 b$ \\
\hline ОСРС 11 & $3.53 \pm 0.30 \mathrm{~h}$ \\
\hline OCPC 12 & $3.69 \pm 0.25 \mathrm{e}$ \\
\hline ОСРС 17 & $3.64 \pm 0.30 \mathrm{~g}$ \\
\hline OCPC 18 & $3.91 \pm 0.14 \mathrm{a}$ \\
\hline ОСРС 19 & $3.77 \pm 0.29 \mathrm{~d}$ \\
\hline ОСРС 20 & $3.69 \pm 0.18 \mathrm{~g}$ \\
\hline ОСРC 21 & $3.47 \pm 0.19 \mathrm{i}$ \\
\hline OCPC 22 & $3.80 \pm 0.19 d$ \\
\hline ОСРC 23 & $4.16 \pm 0.11 \mathrm{a}$ \\
\hline ОСРС 24 & $3.66 \pm 0.21 \mathrm{~g}$ \\
\hline ОСРС 25 & $4.23 \pm 0.16 \mathrm{a}$ \\
\hline OCPC 26 & $4.14 \pm 0.16 \mathrm{a}$ \\
\hline ОСРС 27 & $3.76 \pm 0.27 \mathrm{~d}$ \\
\hline OCPC 28 & $3.63 \pm 0.18 \mathrm{~g}$ \\
\hline ОСРС 29 & $4.17 \pm 0.13 \mathrm{a}$ \\
\hline ОСРС 30 & $3.66 \pm 0.22 \mathrm{~g}$ \\
\hline OCРC 31 & $3.97 \pm 0.28 \mathrm{a}$ \\
\hline ОСРС 32 & $3.67 \pm 0.28 \mathrm{f}$ \\
\hline ОСРС 33 & $3.56 \pm 0.18 \mathrm{~h}$ \\
\hline ОСРС 34 & $3.37 \pm 0.261$ \\
\hline ОСРС 35 & $3.99 \pm 0.27 \mathrm{a}$ \\
\hline ОСРС 36 & $3.71 \pm 0.25 \mathrm{f}$ \\
\hline ОСРС 37 & $3.86 \pm 0.19 \mathrm{~b}$ \\
\hline ОСРС 39 & $3.99 \pm 0.15 \mathrm{a}$ \\
\hline ОСРС 40 & $3.83 \pm 0.12 \mathrm{~d}$ \\
\hline ОСРC 41 & $3.61 \pm 0.31 \mathrm{~g}$ \\
\hline OCРC 42 & $3.97 \pm 0.27 \mathrm{a}$ \\
\hline ОСРC 43 & $4.06 \pm 0.14 \mathrm{a}$ \\
\hline ОСРС 44 & $3.33 \pm 0.101$ \\
\hline ОСРС 45 & $3.60 \pm 0.18 \mathrm{~g}$ \\
\hline ОСРС 46 & $3.82 \pm 0.17 \mathrm{c}$ \\
\hline ОСРС 47 & $3.41 \pm 0.19 \mathrm{k}$ \\
\hline ОСРC 48 & $3.49 \pm 0.33 \mathrm{i}$ \\
\hline ОСРС 49 & $3.89 \pm 0.17 b$ \\
\hline OCPC 50 & $3.97 \pm 0.12 \mathrm{a}$ \\
\hline OCPC 51 & $3.88 \pm 0.10 b$ \\
\hline $\mathrm{CD} 1 \%^{\mathrm{z}}$ & 0.43 \\
\hline
\end{tabular}

${ }^{y}$ Lesion areas $\left(\mathrm{cm}^{2}\right)$ measured 7 days after inoculation on detached leaves of chili leaflets (Arka lohit) with isolates of P. capsici and P. boehmeriae. Data are the means and standard deviation of three independent experiments. Each experiment contained three replicates. Each replicate contained 12 detached leaves. For each row, values followed by a different lowercase letter are significantly different at $P<0.01$, according to Fisher's least significant difference test.

${ }^{\mathrm{z}} \mathrm{CD}$ denotes critical difference at $1 \%$ level. per plants were sensitive to metalaxyl whereas $P$. capsici isolates were intermediate in sensitivity. Isolates of $P$. capsici that were resistant or intermediate in sensitivity to mefenoxam have been found widely within the United States (24), southern Italy (1), and Spain (45). In $P$. capsici, a single, incompletely dominant gene regulates insensitivity to mefenoxam (32). However, no information in the literature is available on sensitivity of $P$. boehmeriae to metalaxyl. Some studies on P. capsici, P. infestans, and P. nicotianae have demonstrated that metalaxyl-resistant isolates were more aggressive that their sensitive counter parts $(10,30,48)$. In the present study, even though $P$. boehmeriae isolates are metalaxyl sensitive, they are highly aggressive compared with $P$. capsici isolates.

Pathogenicity assays with $P$. boehmeriae and $P$. capsici isolates derived from infected chili leaves showed that $P$. boehmeriae isolates were more aggressive than those of the $P$. capsici isolates. Plant breeders and pathologists should note the potential of $P$. boehmeriae to be a major pathogen and develop chili cultivars for resistance to foliar blight and management strategies accordingly. This study is the first that showed that $P$. boehmeriae was responsible for severe leaf blight epidemics in hot pepper production areas of India, and it is not clear whether it is migrated or evolved in India through sexual recombination or any other mechanism because it is not serious pathogen on any crop in any part of the world. Whole-genome sequence analysis and studies of the pathogen population structure over time will provide information on its evolutionary history which can help in the effective deployment of host resistance and fungicides for disease management. From this study, it is not possible to understand the extent of spread of $P$. boehmeriae, and a large-scale survey and population analysis of Phytophthora spp. across chili-growing regions of India is warranted. Integrated management strategies, including the use of pathogen-free transplants, elimination of sources of inoculum, and use of fungicides on foliage, will help chili growers to reduce crop losses caused by this emerged disease.

\section{Acknowledgments}

We thank the Indian Council of Agricultural Research, New Delhi for financial support through the outreach program on diagnosis and management of leaf spot diseases of field and horticultural crops.

\section{Literature Cited}

1. Agosteo, G. E., Raudino, F., and Cacciola, S. O. 2000. Resistance of Phytophthora capsici to metalaxyl in plastic-house capsicum crops in southern Italy. Bull. OEPP 30:257-261.

2. Ali, M. 2006. Chili (Capsicum spp.). Food chain analysis: setting research priorities in Asia. Tech. Bull. No. 38, AVRDC Publ. 06-78:253. AVRDCThe World Vegetable Center, Shanhua, Taiwan.

3. Alizadeh, A., and Tsao, P. H. 1985. Chlamydospore formation in Phytophthora palmivora MF4. Trans. Br. Mycol. Soc. 85:71-79.

4. Allen, S. J., and West, K. L. 1986. Phytophthora boll rot of cotton. Australas. Plant Pathol. 15:34.

5. Aragaki, M., and Uchida, J. Y. 2001. Morphological distinctions between $P$. capsici and P. tropicalis sp. nov. Mycologia 93:137-145.

6. Babadoost, M. 2004. Phytophthora blight: A serious threat to cucurbit industries. (Online feature article) http://www.apsnet.org/online/feature/ cucurbit/

7. Babadoost, M., and Islam, S. Z. 2003. Fungicide seed treatment effects on seedling damping-off of pumpkin caused by Phytophthora capsici. Plant Dis. 87:63-68.

8. Bowers, J. H., Martin, F. N., Tooley, P. W., and Luz, E. D. M. N. 2007. Genetic and morphological diversity of temperate and tropical isolates of Phytophthora capsici. Phytopathology 97:492-503.

9. Brasier, C. M., Beales, P. A., Kirk, S. A., Denman, S., and Rose, J. 2005. Phytophthora kernoviae sp. nov., an invasive pathogen causing bleeding stem lesions on forest trees and foliar necrosis of ornamentals in the UK. Mycol. Res. 109:853-859.

10. Café-Filho, A. C., and Ristaino, J. B. 2008. Fitness of isolates of Phytophthora capsici resistant to mefenoxam from squash and pepper fields in North Carolina. Plant Dis. 92:1439-1443.

11. Chowdappa, P., Brayford, D., Smith, J., and Flood, J. J. 2003. Identification of Phytophthora species affecting plantation crops by RFLP of PCR amplified internal transcribed spacer regions of ribosomal RNA. Curr. Sci. 85:34-36.

12. Chowdappa, P., Brayford, D., Smith, J., and Flood, J. J. 2003. Molecular discrimination of Phytophthora isolates on cocoa and their relationship with coconut, black pepper and bell pepper isolates based on rDNA repeat and 
AFLP fingerprints. Curr. Sci. 84:1235-1238.

13. Chowdappa, P., Brayford, D., Smith, J., and Flood, J. J. 2006. Existence of two molecular subgroups within Phytophthora capsici isolates occurring in India based on r RNA gene repeat. J. Plantation Crops 34:1-12.

14. Chowdappa, P., and Chandramohanan, R. 1997. Occurrence and distribution of mating types of Phytophthora species causing black pod disease of cocoa. Indian Phytopathol. 50:256-260

15. Coffey, M. D., and Bower, L. A. 1984. In vitro variability among isolates of six Phytophthora species in response to metalaxyl. Phytopathology 74:502506.

16. Cooke, D. E. L., Drenth, A., Duncan, J. M., Wagels, G., and Brasier, C. M. 2000. A molecular phylogeny of Phytophthora and related oomycetes. Fungal Genet. Biol. 30:17-32.

17. Cooke, D. E. L., and Duncan, J. M. 1997. Phylogenetic analysis of Phytophthora species based on the ITS1 and ITS2 sequences of ribosomal DNA. Mycol. Res. 101:667-677.

18. Cooke, D. E. L., Duncan, J. M., Williams, N. A., Hagenaar-de Weerdt, M., and Bonants, P. J. M. 2000. Identification of Phytophthora species on the basis of restriction enzyme fragment analysis of the internal transcribed spacer regions of ribosomal RNA.OEPP/EPPO Bull. 30:519-523.

19. Dos Santos, A. F., Luz, E. D. M. N., and De Souza, J. T. 2006. First report of Phytophthora boehmeriae on black wattle in Brazil. Plant Pathol. 55:813.

20. Drenth, A., Wagels, G., Smith, B., Sendall, B., O'Dwyer, C., Irvine, G., and Irwin, J. A. G. 2006. Development of a DNA-based method for detection and identification of Phytophthora species Australas. Plant Pathol. 35:147-159.

21. Erwin, D. C., and Ribeiro, O. K. 1996. Phytophthora Diseases Worldwide. American Phytopathological Society, St. Paul, MN.

22. FAO (Food and Agriculture Organization of the United Nations) 2003. FAO Production Yearbook 2001. FAO, Rome. Page 333

23. FAOSTATS. 2011. http://faostat.fao.org/site/339/default.aspx

24. French-Monar, R., Jones, J. B., and Roberts, P. D. 2006. Characterization of Phytophthora capsici associated with roots of weeds on Florida vegetable farms. Plant Dis. 90:345-350.

25. Gerrettson-Conell, L. 1994. A compendium and classification of the species of the genus Phytophthora DeBary by the canons of traditional taxonomy. Tech. Pap. No. 45:74. Research division, State forests of New South Wales, Sydney.

26. Granke, L. L., Quesada-Ocampo, L. M., and Hausbeck, M. K. 2011. Variation in phenotypic characteristics of Phytophthora capsici isolates from a worldwide collection. Plant Dis. 95:1080-1088.

27. Hausbeck, M. K., and Lamour, K. H. 2004. Phytophthora capsici on vegetable crops: research progress and management challenges. Plant Dis. 88:1292-1303

28. Islam, S. Z., Babadoost, M., Lambert, K. N., Ndeme, A., and Fouly, H. M 2004. Characterization of Phytophthora capsici isolates from processing pumpkin in Illinois. Plant Dis. 89:191-197.

29. Jung, T., and Nechwatal, J. 2008. Phytophthora gallica sp. nov., a new species from rhizosphere soil of declining oak and reed stands in France and Germany. Mycol. Res. 112:1195-1205.

30. Kadish, D., and Cohen, Y. 1988. Fitness of Phytophthora infestans isolates from metalaxyl sensitive and -resistant populations. Phytopathology 78:912915.

31. Kroon, L. P. N. M., Brouwer, H., de Cock, A. W. A. M., and Govers, F. 2012. The genus Phytophthora anno 2012. Phytopathology 102:348-364.

32. Lamour, K. H., and Hausbeck, M. K. 2000. Mefenoxam insensitivity and the sexual stage of Phytophthora capsici in Michigan cucurbit fields. Phytopathology 90:396-400.

33. Mchau, G. R., and Coffey, M. D. 1995. Evidence for the existence of two subpopulations in Phytophthora capsici and a redescription of the species. Mycol. Res. 99:89-102.

34. Nei, M., and Kumar, S. 2000. Molecular Evolution and Phylogenetics.
Oxford University Press, New York.

35. Nelson, S. C., and Abad, Z. G. 2010. Phytophthora morindae, a new species causing black flag disease on noni (Morinda citrifolia L.) in Hawaii. Mycologia 102:122-134

36. Paplomatas, E. J., Elena, K and Lascaris, D. 1995. First report of Phytophthora boehmeriae causing boll rot of cotton. Plant Dis. 79:860 Online publication. doi:10.1094/PD-79-0860C

37. Quesada-Ocampo, L. M., Granke, L. L., Mercier, M. R., Olsen, J., and Hausbeck, M. K. 2011. Investigating the genetic structure of Phytophthora capsici populations. Phytopathology 101:1061-1073.

38. Raeder, U., and Broda, P. 1985. Rapid preparation of DNA from filamentous fungi. Appl. Microbiol. 1:17-20.

39. Ristaino, J. B. 1990. Intraspecific variation among isolates of Phytophthora capsici from pepper and cucurbit fields in North Carolina. Phytopathology 80:1253-1259.

40. Ristaino, J. B., and Johnston, S. A. 1999. Ecologically based approaches to management of Phytophthora blight on bell pepper. Plant Dis. 83:10801089.

41. Ristaino, J. B., Madritch, M., Trout, C. L., and Parra, G. 1998. PCR amplification of ribosomal DNA for species identification in the plant pathogen genus Phytophthora. Appl. Environ. Microbiol. 64:948-954.

42. Sawada, K. 1927. Report of the Government Research Institute. Rep. Dep. Agric. Res. Inst. Formosa 27:10-11.

43. Shen, G., Wang, Y. C., Zhang, W. L., and Zheng, X. B. 2005. Development of a PCR assay for the molecular detection of Phytophthora boehmeriae in infected cotton. J. Phytopathol. 153:291-296.

44. Silvar, C., Duncan, J. M., Cooke, D. E. L., Williams, N. A., Diaz, J., and Merino, F. 2005. Development of specific PCR primers for identification and detection of Phytophthora capsici Leon. Eur. J. Plant Pathol. 112:4352.

45. Silvar, C., Merino, F., and Diaz, J. 2006. Diversity of Phytophthora capsici in Northwest Spain: analysis of virulence, metalaxyl response, and molecular characterization. Plant Dis. 90:1135-1142.

46. Spice India volumes. 2006-2010. Publisher Spice Board India. Cochin, Kerala, India.

47. Tamura, K., Peterson, D., Peterson, N., Stecher, G., Nei, M., and Kumar, S. 2011. MEGA5: molecular evolutionary genetics analysis using maximum likelihood, evolutionary distance, and maximum parsimony methods. Mol. Biol. Evol. 28:2731-2739.

48. Timmer, L. W., Graham, J. H., and Zitko, S. E. 1998. Metalaxyl-resistant isolates of Phytophthora nicotianae: occurrence, sensitivity, and competitive parasitic ability on citrus. Plant Dis. 82:254-261.

49. Tooley, P. W., Carras, M. M., and Falkenstein, K. F. 1996. Relationships among group IV Phytophthora species inferred by restriction analysis of the ITS2 region. J. Phytopathol. 144:363-369.

50. Uchida, J. Y., and Aragaki, M. 1985. Occurrence of chlamydospores in Phytophthora capsici. Mycologia 77:832-835.

51. White, T. J., Bruns, T., Lee, S. B., and Taylor, J. 1990. Amplification and direct sequencing of fungal ribosomal RNA genes for phylogenetics. Pages 315-322 in: PCR Protocols: A Guide to Methods and Applications. M. A. Innis, D. H. Gelfard, J. J. Sninsky, T. J. White, eds. Academic Press, San Diego, CA.

52. Wolcan, S., and Lori, G. 2001. Basal rot of Gerald ton wax plant caused by Phytophthora boehmeriae. Plant Dis 85:98.

53. Yoon, J. Y., Green, S. K., Talekar, N. S., and Chen, J. T. 1991. Pepper improvement in the tropics: problems and the AVRDC approach. Pages 86-98 in: Tomato and Pepper Production in the Tropics. Proc. Int. Symp. Integr. Manage. Practices, Tainan. AVRDC, Taiwan.

54. Zhang, Z. G., Li, Y. Q., Fan, H., Wang Y. C., and Zheng X. B. 2006. Molecular detection of Phytophthora capsici in infected plant tissues, soil and water. Plant Pathol. 55:770-775. 